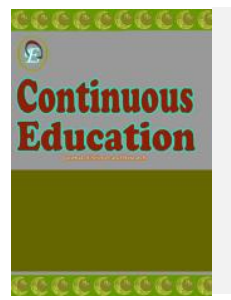

\title{
Peran Kepala Sekolah Dalam Menciptakan Iklim Kerja Yang Kondusif di SD IT Ummi Aida Medan
}

\author{
Nurul Ajima Ritonga ${ }^{1}$ \\ 1STIT, Karimun, Indonesia
}

\section{Corresponding Author: Muhammad Fadhli, @ajimarietonga94@gmail.com}

ARTICLE INFO

Article history:

Received

21 October 2020

Revised

24 October 2020

Accepted

25 October 2020

\section{ABSTRACT}

Penelitian ini bertjuan untuk mengetahui : 1) upaya yang dilakukan kepala sekolah dalam menciptakan iklim kerja yang kondusif di SDIT Ummi Aida Medan, 2) Faktor-Faktor pendukung dan penghambat dalam mewujudkan iklim kerja yang kondusif di SDIT Ummi Aida Medan. Metode yang digunakan dalam penelitian ini adalah metode kualitatif deskriptif jenis penelitian studi kasus. Sumber data penelitian ini adalah data primer dan sekunder, informan utamanya adalah kepala sekolah, Guru dan peserta didik sebagai karakteristik objek penelitian, dilengkapi dengan dokumen dan arsip yang turut mendukung data penelitian. Tehnik sampling yang digunakan adalah Purposive sampling. Tehnik pengumpulan data yang digunakan adalah observasi, wawancara dan dokumentasi. Analisis data yang digunakan adalah analisis interaktif yang meliputi reduksi data, penyajian data, dan penarikan kesimpulan. Adapun hasil penelitian yang telah dilakukan sebagai berikut: 1. Upaya Kepala Sekolah dalam menciptakan iklim kerja yang kondusif adalah a. Kepala sekolah menjalin komunikasi interaktif dengan guru melalui pendekatan formal maupun informal sebagai upaya menciptakan harmonisasi, b. Kepala sekolah memberikan reward baik berupa pujian maupun pemberian hadiah sebagai bentuk apresiasi terhadap kualitas kerja guru, c. Memberikan kesempatan kepada guru untuk membantu peserta didik dalam menumbuhkembangkan keterampilan melalui kegiatan ekstrakurikuler khususnya di bidang agama dan seni. 2. Faktor pendukung dan penghambat dalam upaya menciptakan iklim kerja yang kondusif di SDIT Ummi Aida Medan yaitu: a. Kesadaran guru akan pentingnya teamwork dalam maksimalisasi pekerjaan, b. dukungan dari pihak yayasan dalam memfasilitasi dan menyediakan sarana yang turut mewujudkan lingkungan kerja yang nyaman bagi guru. faktor penghambatnya adalah kepribadian dan prinsip personal guru yang berbeda-beda.

\section{Keywords Peran Kepala Sekolah, Iklim Kerja yang kondusif}

How to cite

Name. (2020). Tittle. Journal Continuous Education, 1(1). 43-55.
http://pusdikra-publishing.com/index.php/josr/issue/current

\section{PENDAHULUAN}

Sekolah merupakan lembaga pendidikan formal yang memiliki peran penting dalam mencerdaskan kehidupan Bangsa, Maju atau mundur nya suatu Negara sangat dipengaruhi oleh kualitas sumberdaya manusianya, Pendidikan 
Journal Continuous Education

Volume 1, Issue 1, November 2020

Page 43-55

bertujuan untuk mengembangkan potensi sumberdaya manusia yang terintegrasi melalui kemampuan manusia dalam mempertahankan hidupnya dan memberikan kontribusi terhadap lingkungan dan orang-orang di sekitarnya. Sekolah terdiri dari beberapa elemen yang saling bersinergi satu sama lain, setiap elemen memiliki fungsi, peran dan tugas masing-masing dalam mejalankan setiap aktivitas yang ada di persekolahan guna mewujudkan impian dan cita-cita bersama. Tujuan pendidikan yang menjadi acuan setiap sekolah dalam menunjukkan eksistensinya tentunya tidak lepas dari tujuan pendidikan Nasional, tujuan Intitusional dan tujuan kurikuler setiap pembelajaran.

Kepala sekolah merupakan elemen penting yang diharapkan mampu mengerahkan elemen lainnya dalam melaksanakan kegiatan organisasi dengan cara mampu mempengaruhi para anggotanya untuk melaksanakan tugas dengan sebaik-baiknya guna mencapai tujuan organisasi. Selain kepala sekolah, guru juga memiliki peran dalam mewujudkan iklim kerja yang kondusif, sebagai ujung tombak keberhasilan proses pendidikan melalui kegiatan pembelajarang yang ada di kelas, guru diharapkan menjunjung tinggi nilainilai yang dianut oleh sekolah baik dalam bersikap, berperilaku dan bekerja. Guru sebagai elemen yang menjadi pelaksana kebijakan dan keputusan yang dibuat oleh kepala sekolah diharapkan mampu menunjukkan kualitas kerja dan loyalitas terhadap kepala sekolah dalam mewujudkan visi dan misi sekolah sehingga akan menciptakan iklim kerja yang kondusif.

Selain dituntut untuk bekerja sesuai arahan dan bimbingan kepala sekolah, tentunya guru bertanggungjawab terhadap keberhasilan peserta didik di dalam proses pembelajaran, guru harus mampu memberikan arahan guna mewujudkan peserta didik yang memiliki kecakapan hidup, oleh sebab itu untuk melihat dan menilai apakah iklim kerja yang kondusif tentunya dilihat dari semua komponen yang ada didalam pendidikan dengan melibatkan komponen yang tidak hidup seperti fasilitas pendidikan dan sarana lainnya. Maka sebagai pemimpin kepla sekolah diharapkan mampu menghandel semua komponen pendidikan sehingga saling bekerjasama dalam mewujudkan instansi yang dipercaya oleh masyarakat sebagai wadah untuk peningkatan kualitas sumberdaya manusia.

Peran kepala sekolah adalah suatu perilaku yang dimiliki oleh kepala sekolah yang harus dijalankan sesuai dengan kedudukan kepala sekolah sebagai pemimpin. Menurut (Depdiknas , 2006) ada tujuh peran utama kepala sekolah menurut kebijakan pendidikan nasional yaitu: (1) edukator (pendidik); (2) manajer; (3) administrator; (4) supervisor (penyelia); (5) leader (pemimpin); (6) pencipta iklim kerja; dan (7) wirausahawa. 
Journal Continuous Education

Volume 1, Issue 1, November 2020

Page 43-55

Iklim organisasi merupakan kualitas lingkungan internal yang secara relatif terus berlangsung, dialami oleh anggota organisasi, mempengaruhi perilaku setiap anggotanya (Wirawan, 2009). Iklim kerja adalah persepsi setiap anggota organisasi baik secara individual dan kelompok dan mereka secara tetap berhubungan dengan organisasi (seperti stakeholder, orangtua dan lingkungan kerja) mengenai apa yang ada atau terjadi di lingkungan internal organisasi secara rutin, yang mempengaruhi sikap dan perilaku organisasi dan kinerja anggota organisasi yang kemudian menentukan kinerja organisasi." Jadi iklim kerja merupakan cara pandang serta harapan-harapan setiap anggota terhadap organisasi.

Sepuluh dimensi iklim kerja, yaitu:1. Tantangan (challenge) Keterlibatan dan komitmen karyawa terhadap organisasi 2. Kemerdekaan (freedom) Sampai seberapa tinggi karyawan diberi kebebasan untuk bertindak 3. Dukungan untuk ide-ide (Support for ideas) Sikap manajemen dan karyawan terhadap ide baru 4. Kepercayaan (Trust) Keamanan emosional dan kepercayaan hubungan antar anggota dalam organisasi 5. Semangat (Spirit) Dinamika dalam organisasi 6. Keintiman Kemudahan yang ada dalam organisasi 7. Debat (Debate) Sampai seberapa tinggi perbedaan pendapat serta ide-ide dari pengalaman yang ada dalam organisai 8. Konflik (Conflicks) Adanya tensi personal dan kelompok 9. Pengambilan Resiko (Risk Taking) Kemauan untuk mendekorasi keputusan dalam organisasi 10. Ide dan Waktu (Idea and Time) Waktu yang digunakan untuk mengembangakan ide-ide baru (Helmawati, 2014).

(Supardi, 2014) Iklim kerja di sekolah tentunya merupakan interaksi yang terjadi diantara personil yang ada di skeolah, baik dari pemimpin dalam hal ini kepala sekolah, guru dan tenaga kependidikan serta peserta didik itu sendiri. Dari hasil penelitian yang dilakukan oleh beberapa peneliti yang dilakukan, sekolah dengan iklim kondusif mempunya ciri-ciri seperti :

1. Sekolah memiliki nilai etika-moralitas dan etos yang dianggap sangat krusial.

2. Kepala sekolah, guru dan karyawan serta siswa menunjukkan sikap kepedulian dan memiliki loyalitas terhadap nilai-nilai budaya dan tujuan sekolah.

3. Sekolah menyediakan lingkungan dan suasana yang menyenangkan, menggairahkan, dan nyaman bagi guru dan peserta didik.

4. Adanya sikap saling mempercayai dan saling menghargai sesama baik di antara guru dan peserta didik, dalam hal ini memiliki alur komunikasi yang terbuka. 
5. Kepala sekolah, guru dan peserta didik mempunyai semangat yang tinggi dan saling bekerjasama untuk mencapai prestasi belajar yang tinggi.

6. Peserta didik saling menaruh perhatian lebih terhadap sesamanya dan terhadap benda-benda milik mereka.

7. Adanya disiplin dan kesempatan bagi peserta didik untuk mengambil tanggungjawab di sekolah.

8. Tingkat mengulang kelas yang rendah dan rendahnya kasus kenakalan remaja

9. Adanya rasa bahagia dan semangat juang yang tinggi di kalangan guru, sehingga mereka tidak perlu pindah ke sekolah lain.

Upaya menciptakan budaya dan iklim kerja yang kondusif, kepala sekolah seyogiyanya memahami prinsip-prinsip sebagai berikut : (1) tinggi rendahnya kualitas kerja guru sangat dipengaruhi oleh seberapa menarik dan menyenangkan kegiatan dan pekerjaan yang mereka lakukan, (2) tujuan kegiatan harus di disusun secara jelas dan disampaikan kepada tenaga pengajar, sehimgga guru paham akan tujuan pekerjaannya, lalu guru perlu dilibatkan dalam penyusunan tujuan. (3) menginformasikan kepada guru mekanisme setiap pekerjaannya. (4) pemberian reward menjadi pilihan dan cara yang efektif dari pada pemberian hukuman, namun tidak bias dipungkiri pemberian punishment juga diperlukan pada kondisi tertentu, (5) memenuhi kebutuhan sosio-psiko-fisik guru, sehingga mereka merasa puas dengan pekerjaannya (Mulyasa : 2003).

(Agustin, 2010) Faktor-faktor yang mempengaruhi iklim kerja adalah sebagai berikut: fleksibilitas, tanggungjawab, standard, upah kerja, kejelasan, komitmen, struktur, dukungan dan kepemimpinan. Berikut penjelasan dari faktor-faktor iklim kerja tersebut.

1. Fleksibilitas, Fleksibilitas merupakan pemberiaan keleluasaan kepada karyawan oleh lembaga/ organisasi untuk bertindak sebagai bentuk penyesuaian diri terhadap tugas-tugas yang diberikan.

2. Tanggungjawab, Tanggungjawab merupakan perasaan karyawan tentang pelaksanaan tugas yang diemban dengan rasa tanggungjawab atas hasil yang dicapai.

3. Standar, Standar merupakan perhatian manajemen yang dibuat oleh perusahaan tentang keberhasilan tugas yang dilaksanakan dalam hal ini menyangkut tentang tingkat penerimaan dan toleransi terhadap kesalahan atau hal-hal yang kurang baik atau kurang sesuai,

4. Umpan balik, Umpan balik merupakan pemberian imbalan dan hadiah sebagai bentuk penghargaan dan pengakuan oleh lembaga terhadap 
karyawan atas keberhasilan pekerjaan yang mereka lakukan. Dalam hal ini karyawan mengerahkan semua kemampuan nya dan perusahan mengganggap hasil kerja mereka penting dalam mewujudkan tujuan bersama.

5. Kejelasan, Kejelasan merupakan perasaan karyawan bahwa mereka mengatahui apa yang diharapkan dari mereka berkaitan dengan pekerjaan, peranan dan tujuan lembaga/perusahaan.

Berdasarkan hasil obervasi awal yang dilakukan di SDIT Ummi Aida Medan, penulis melihat iklim kerja yang ada di SD IT Ummi Aida Medan masih menunjukkan kondisi yang kurang kondusif hal ini dibuktikan dengan masih ada guru dan siswa yang datang terlambat ke sekolah, ini terlihat jelas di luar pagar, ada nya siswa yang di tahan di luar tanpa diizinkan masuk sampai kegiatan berbaris di pagi hari selesai. Tidak hanya itu, sekolah memiliki lapangan yang sempit, untuk jumlah siswa yang mencapai ratusan dengan kapasitas lapangan kecil tentunya butuh tata kelolah yang baik dalam mengkondusifkan anak anak yang masih beresekolah di jenjang SD.

Berdasarkan kondisi yang terjadi di lapangan, maka penulis melakukan penelitian secara mendalam terhadap iklim kerja di SDIT Ummi Aida Medan. Dalam hal ini berjudul “Upaya Kepala Sekolah dalam Menciptakan Iklim Kerja yang kondusif di SDIT Ummi Aida Medan

\section{METODE PENELITIAN}

Penelitian ini menggunakan pendekatan kualitatif deskriptif dengan jenis studi kasus, dimana peneliti berusaha menggambarkan kondisi atau fakta berdasarkan kasus yang terjadi di lapangan. Studi kasus yang dilakukan sebagai upaya dalam memperoleh pemecahan masalah yang terjadi di lapangan. (Moleong, 2009) penelitian kualitatif adalah penelitian dalam memahami fenomena tentang apa yang dialami oleh objek penelitian dengan cara deskriptif dalam bentuk kata-kata dan bahasa, pada suatu konteks khusus alamiah dan dengan memanfaatkan berbagai metode ilmiah. Strauss dan Corbin dalam (Salim dan Syahrum, 2012) menjelaskan, penelitian kualitatif adalah suatu jenis penelitian sebagai prosedur untuk menemukan sesuatu dengan tidak menggunakan prosedur statistik atau kuantifikasi. Dalam arti lain penelitian kualitatif adalah penelitian tentang aspek kehidupan seseorang, seperti cerita, perilaku, dan juga tentang fungsi organisasi, gerakan social suatu hubungan timbal balik 
Journal Continuous Education

Volume 1, Issue 1, November 2020

Page 43-55

\section{HASIL DAN PEMBAHASAN}

Lingkungan kerja yang kondusif tentu tercipta dari kerjasama antara kepala sekolah selaku pemimpin organisasi dan para guru, pegawai serta siswa yang juga memiliki peran masing-masing dalam menciptakan lingkungan sekolah yang aman dan nyaman. Lingkungan kerja tentunya sangat erat kaitannya dengan komunikasi dan interaksi yang terjalin antara kepala sekolah dengan para guru. Maka selaku pemimpin kepala sekolah memiliki tanggungjawab terhadap kendali manajemen. Oleh sebab itu keterampilan dalam mempengaruhi para anggota organisasi sangat diperlukan. Dan kepala sekolah adalah pemeran utamanya. Kepala sekolah dituntut mampu membawa lembaganya menjadi lembaga yang mampu berdaya saing dan mampu mengikuti peregerakan kemajuan teknologi sehingga berpotensi dalam memajukan pendidikan di Indonesia. Untuk mewujudkan sekolah yang mampu berdaya saing, kepala sekolah tentunya memiliki tugas, peran dan tanggungjawab yang lebih dari anggota organisasi sekolah lainnya. Kepala sekolah harus mampu mengerahkan seluruh anggotanya/guru untuk berpartisipasi aktif dalam mewujudkan tujuan pendidikan dan cita-cita bangsa. Kepala sekolah dan guru adalah rekan kerja yang tidak bisa dipisah dan harus selalu memiliki visi dan misi yang sama dalam menciptakan suasana kerja yang baik.

Guru merupakan pilar dan ujung tombak pendidikan, hal ini disebabkan guru adalah pemimpin proses pembelajaran. Dimana proses pembelajaran merupakan proses terjadinya pendidikan, perubahan perilaku dan peningkatan kepribadian peserta didik sebagai hasil ataupun output dari proses belajar itu sendiri. Guru juga merupakan teladan bagi peserta didik, selain mengajar di dalam kelas, mentransfer ilmu pengetahuan, guru juga harus membimbing dan mendidik peserta didik agar sesuai dengan nilai-nilai keagamaan, etika, moral, sosial dan budaya agar menjadi manusia yang berdayaguna dan memiliki rasa kepedulian terhadap sesama dan lingkungan. Sebagai pemimpin kepala sekolah dengan segenap kompetensi dan keterampilan turut membantu guru dalam mewujudkan iklim kerja yang kondusif, hal ini dilakukan dengan berbagai upaya yang saling bersinergi. Iklim kerja yang nyaman dan kondusif merupakan kebutuhan setiap anggota organisasi dalam melakukan tugas dan tanggungjawab, sehingga bekerja merupakan suatu hal yang sangat menyenangkan bukan menjadi beban. Ketika guru merasa nyaman di tempat kerja ini juga akan meningkatkan kualitas kerja guru. Guru akan bekerja dengan ikhlas dan berusaha memberikan yang terbaik. Karena itu peran kepala sekolah seyogiyanya adalah orang yang paling mengerti terhadap kebutuhan 
Journal Continuous Education

Volume 1, Issue 1, November 2020

Page 43-55

dan hal-hal yang mendukung semangat kerja guru melalui iklim kerja yang kondusif.

Iklim kerja yang yang baik tidak terlepas dari pengaruh suasana kerja secara fisik maupun komunikasi yang terjalin diantara orang-orang yang bekerja di dalam organisasi. Kenyamanan secara fisik diwujudkan melalui pengadaan fasilitas yang memadai, baik fasilitas yang berhubungan dengan sarana prarasana pendidikan, serta kelengkapan media dalam proses pembelajaran. Selain memenuhi kebutuhan fasilitas atau sarana dan prasarana yang memadai, kepala sekolah juga membuat seperangkat mekanisme kerja atau perangkat selain sarana dan prasarana. Mekanisme kerja ini disiapkan agar guru memahami tugas dan tanggungjawabnya, memiliki spirit kerja yang baik, dan memiliki persaingan kerja yang sehat. Kemudian kepala sekolah membangun keharmonisan dan komunikasi yang baik yaitu dengan membangun moral budaya sekolah yang baik, berupa senyum, sapa, salam, santun dan keterbukaan. Dengan menciptakan suasana sekolah seperti ini diharapkan dapat meciptakan iklim kerja yang baik.

\section{Upaya Kepala Sekolah dalam Menciptakan Iklim Kerja yang Kondusif di SD IT Ummi Aida Medan.}

Peranan kepala sekolah sebagai pencipta iklim kerja sangatlah penting dalam memotivasi guru dalam melaksanakan tugasnya sehingga akan meningkatkan kualitas kerja guru. Iklim kerja yang kondusif akan membuat rasa nyaman sehinggan guru dapat bekerja dan mengerakkan semua kemampuannya. Iklim kerja adalah persepsi anggota organisasi (secara individual dan kelompok) dan mereka yang secara tetap berhubungan dengan organisasi (misalnya siswa, guru, kepala sekolah dan stakeholder) mengenai apa yang ada atau terjadi di lingkungan internal organisasi secara rutin, yang mempengaruhi sikap dan perilaku organisasi dan kinerja anggota organisasi yang kemudian menentukan kinerja organisasi. Jadi iklim kerja merupakan harapan-harapan serta cara pandang individu terhadap organisasi. Program pembelajaran di sekolah tidak akan berjalan dengan baik tanpa adanya iklim kerja yang kondusif.

Iklim kerja merupakan suatu kondisi atau keadaan suasana kerja dalam suatu organisasi. Iklim kerja yang menyenangkan akan tercipta, apabila hubungan antar manusia berkembang dengan harmonis. Keadaan iklim yang harmonis ini sangat mendukung terhadap kinerja seseorang yang akan berdampak pula pada etos kerjanya.

Berdasarakan penjabaran diatas, sasaran pengembangan iklim meliputi (1) tingkat kenyamanan, (2) proses pengajaran dan pembelajaran (3) Hubungan 
Journal Continuous Education

Volume 1, Issue 1, November 2020

Page 43-55

interpersonal antara siswa dengan siswa, siswa dengan guru, maupun guru dengan orang tua serta (4) hubungan kelembagaan lingkungan dengan sekolah.

Berdasarkan hasil wawancara dengan kepala sekolah SDIT Ummi Aida Medan, dalam hal menciptakan rasa nyaman selama bekerja di sekolah, Kepala sekolah menjalin komunikasi yang baik dengan guru, dalam hal pekerjaan, kepala sekolah memberikan arahan dan penjelsan mengenai tugas yang akan disiapkan oleh guru, dengan bahasa yang lembut dan persuasif, namun tetap memegang teguh prinsip disiplin dengan memberikan masa tenggang waktu, tidak jarang pula kepala sekolah memberikan keterangan mengenai suatu tugas atau penjelsan singkat yang turut menambah wawasan dan masukan kepada guru yang hendal mengerjakan sesuatu.

Misalnya untuk perubahan yang terjadi dalam skala nasional yang berasal dari pusat terkait dengan proses pembelajaran, kepala sekolah akan memberikan kesempatan kepada guru untuk belajar dan memahami hal-hal baru tersebut melalui kegiatan, seminar atau pelatihan baik yang diselenggarkan oleh pihak luar sekolah mapun kegiatan yang dilakukan di sekolah tersebut. Tidak hanya itu kepala sekolah sekolah juga selalu memberikan arahan kepada para guru untuk saling membantu dalam menyelesaikan masalah, baik masalah yang timbul selama proses pembelajaran dikelas, misalnya ketidakmampuan guru dalam mengorganisasikan atau menghandel kelas, maupun masalah yang timbul di luar ruang belajar.

Dalam kesempatan yang lebih santai guru menjalin komunikasi dalam bentuk gurauan atau candaan dengan tujuan agar komunikasi yang terjalin di jam kerja tetap memegang prinsip kekeluargaan, dalam menjalin kenyamanan dalam berkomunikasi, kepala sekolah juga memiliki program liburan akhir tahun sesame pegawai, baik kepala sekolah maupun guru, tentunya dalam hal ini yayasan juga ikut berpartisipasi dalam menciptakan hubungan yang harmonis dan kekeluargaan.

Rasa nyaman sangat dibutuhkan dan diinginkan oleh semua orang, di lembaga pendidikan rasa nyaman sudah menjadi suatu keharusan yang harus dicapai melalui lingkungan yang kondusif, kelas yang bersih, serta hubungan harmonis yang tercipta dari interaksi semua masyarakat sekolah. Menjaga fasilitas sekolah agar tetap bersih menjadi salah satu perhatian penting bagi kepala sekolah dalam menciptakan iklim kerja yang kondusif. Hasil wawancara yang dilakukan dengan kepala sekolah memberikan penjelasan bahwa untuk hal kebersihan kepala sekolah dan yayasan saling bersinergi dalam memastikan kelas dan lingkungan sekolah tetap bersih. Tentunya untuk hal kebersihan menjadi tanggungjawab semua masyarakat sekolah, akan tetapi secara spesifik kebersihan sekolah menjadi tanggungjawab penuh para pegawai yang 
Journal Continuous Education

Volume 1, Issue 1, November 2020

Page 43-55

ditugaskan sebagai tenaga kebersihan. Namun kebersihan lingkungan juga merupakan tanggungjawab masyarakat sekolah, dalam ini kepala sekolah dan guru menanamkan nilai-nilai peduli kebersihan kepada seluruh siswa dengan membuang sampah pada tempatnya, makan tidak berserakan dan menjaga kebersihan lantai kamar mandi.

Kepala sekolah dan yayasan bekerjasama dalam menyediakan tempat sampah dengan berbagai kategori sampah, jadi untuk sampah sendiri kepala sekolah memberikan kesempatan kepada murid untuk menentukan jenis sampah dan membuangnya di tempat yang sudah disediakan dengan pelabelan jenis sampah organic dan nonorganik.Untuk kebersihanan sekolah SDIT Ummi Aida pernah mendapatkan prestasi peringkat ke dua sekolah terbersih se kecamatan Medan Tembung. Ini merupakan suatu bukti bahwa untuk kebersihan fasilitas kepala sekolah telah melakukan upaya yang maksimal dalam rangka menciptakan suasana nyaman.

Selain kelengkapan fasilitas, menjaga kebersihan lingkungan, menciptakan Susana kerja yang harmonis dan kekeluargaan, kepala sekolah juga berupaya memberikan kesejahteraan melalui kenaikan upah dan pemberian hadia kepada guru yang berprestasi, tidak hanya itu kepala sekolah juga berupaya menjalin komunikasi yang baik kepada pegawai lain selain guru yang turut membantu dalam mewujdukan lingkungan kerja yang kondusif.

Peranan seorang guru sangatlah dibutuhkan keberadaannya dalam proses belajar mengajar, termasuk disini kualitas kerja guru dalam proses belajar mengajar, sehingga dapat berpengaruh dalam aktivitas belajar siswa. Karena kepala sekolah yang kompeten akan dapat menumbuhkan dampak positif bagi guru itu sendiri. Dengan demikian peran kepala sekolah dalam proses belajar mengajar yang termasuk di dalamnya membimbing, mengelola, mengarahkan serta menggerakkan orang lain atau guru dengan baik, maka akan dapat mencapai tujuan yang diinginkan.

Berdasarkan hasil wawancara penulis dengan kepala sekolah, beliau menjelaskan bahwa usaha-usaha yang dilakukan dalam menciptakan iklim kerja yang kondusif meliputi iklim fisik maupun proses kerja antara lain:

a. Menjamin lingkungan sekolah tetap bersih dan nyaman untuk anak anak

b. Melengkapi fasilitas, sarana dan prsaranan dan media pembelajaran.

c. Menjalin hubungan yang harmonis terhadap tenaga pengajar (para guru) baik dalam Susana kerja yang serius, maupun kondisi kerja dengan suasana kekeluargaan.

d. Memberikan kesejahteraan kepada para guru yang memadai.

e. Melengkapi fasilitas, sarana dan prsaranan dan media pembelajaran. 
Journal Continuous Education

Volume 1, Issue 1, November 2020

Page 43-55

f. Memberikan hadia bagi guru yang memiliki prestasi dalam memajukan sekolah

g. Mengkontrol dan mengevaluasi guru dalam menjalankan tugas mereka.

\section{Faktor-faktor yang Mempengaruhi Terciptanya Iklim Kerja yang} Kondusif di SDIT Ummi Aida Medan

Kepala sekolah memiliki komitmen dan motivasi yang kuat untuk meningkatkan mutu sekolah secara optimal. Guru memiliki komitmen dan harapan yang tinggi bahwa siswanya dapat mencapai prestasi yang maksimal, walaupun dengan segala keterbatasan sumber daya pendidikan sekolah. Siswa juga mempunyai motivasi untuk selalu meningkatkan diri untuk berprestasi sesuai dengan bakat dan kemampuannya. Harapan tinggi dari ketiga unsur sekolah ini merupakan salah satu faktor yang menyebabkan sekolah selalu dinamis untuk selalu menjadi lebih baik dari keadaan sebelumnya.

(Supardi, 2014) Iklim kerja yang kondusif mempunya ciri-ciri sebagai berikut:

1. Sekolah memiliki nilai etika-moralitas dan etos yang dianggap sangat krusial.

2. Kepala sekolah, guru dan karyawan serta siswa menunjukkan sikap kepedulian dan memiliki loyalitas terhadap nilai-nilai budaya dan tujuan sekolah.

3. Sekolah menyediakan lingkungan dan suasana yang menyenangkan, menggairahkan, dan nyaman bagi guru dan peserta didik.

4. Adanya sikap saling mempercayai dan saling menghargai sesama baik di antara guru dan peserta didik, dalam hal ini memiliki alur komunikasi yang terbuka.

5. Kepala sekolah, guru dan peserta didik mempunyai semangat yang tinggi dan saling bekerjasama untuk mencapai prestasi belajar yang tinggi.

6. Peserta didik saling menaruh perhatian lebih terhadap sesamanya dan terhadap benda-benda milik mereka.

7. Adanya disiplin dan kesempatan bagi peserta didik untuk mengambil tanggungjawab di sekolah.

8. Tingkat mengulang kelas yang rendah dan rendahnya kasus kenakalan remaja

9. Adanya rasa bahagia dan semangat juang yang tinggi di kalangan guru, sehingga mereka tidak perlu pindah ke sekolah lain.

Berdasarkan poin yang telah dijelaskan di atas, iklim kerja yang kondusif diciptakan oleh interaksi semua warga sekolah. Iklim kerja yang kondusif 
dilihat dari persfektif, iklim kerja dari segi fisik dan iklim kerja yang tercipta dari proses interaksi yang dilakukan oleh guru, siswa dan kepala sekolah. Iklim kerja yang kondusif tentu tidak terlepas dari faktor-faktor.

Berdasarkan hasil penelitian yang dilakukan bahwa adapun faktor yang mempengaruhi iklim kerja di SDIT Ummi Aida Medan adalah:

1. Komunikasi yang baik

Komunikasi yang baik sangat efektif dalam mewujudkan iklim kerja yang baik, terutama antarwarga sekolah dan juga antara sekolah dengan masyarakat, sehingga kegiatan-kegiatan yang dilakukan oleh setiap warga sekolah dapat diketahui dan dipantau kemajuan dan perkembangannya. Komunikasi yang baik tercipta dari keterampilan kepala sekolah dalam memberikan penjelasam seputar tugas yang diberikan, tidak hanya itu, kepala sekolah juga memberikan kepada guru untuk berkaya melalui kreatifitas dan meminta pendapat atau ide yang diharapkan dapat dijadikan masukan dalam upaya mewujudkan visi dan misi sekolah. Dengan cara ini, keterpaduan semua kegiatan sekolah dapat diupayakan untuk mencapai tujuan dan sasaran sekolah yang telah ditetapkan. Selain itu, komunikasi yang baik juga akan membentuk teamwork yang kuat, kompak dan cerdas sehingga berbagai kegiatan sekolah dapat dilakukan secara merata oleh seluruh warga sekolah. Kepala sekolah berupaya menciptakan lingkungan yang komunikatif melalui candaan atau komunikasi yang lebih menyenangkan dalam mengarahkan guru dan staf lainnya. Dalam hal ini kepala sekolah mampu mewujudkan teamwork yang kompak, cerdas dan dinamis. Kebersamaan (teamwork) merupakan karakteristik yang dituntut oleh kurikulum tingkat satuan pendidikan, karena output pendidikan merupakan hasil kolektif warga sekolah, bukan hasil individual. Karena itu, budaya kolaboratif antar fungsi dan antarindividu dalam sekolah, harus merupakan kebiasaan hidup seharihari warga sekolah.

2. Menetapkan secara jelas tugas serta mewujudkan visi dan misi sekolah. Visi dan misi akan menentukan arah pengembangan sekolah. Sekolah harus menyatakan dengan jelas tentang keseluruhan visi, misi, kebijakan, tujuan dan sasaran tersebut merupakan keputusan bersama antara kepala sekolah, guru, siswa dan jika perlu orang tua. Visi, misi, kebijakan, tujuan dan sasaran tersebut menjadi komitmen bersama-sama warga sekolah yang tercermin dalam perilaku dan tindakan nyata untuk mewujudkannya. 
3. Pemberian umpan balik terhadap hasil kerja guru, dalam hal ini pemberian reward (apresiasi) baik dengan pujian maupun pemberian hadiah yang diadakan setiap satu semester bagi guru yang selalu meningkatkan kualitas kerja, beberapa indicator yang dijadikan sebagai acuan pemberian hadiah diantaranya adalah kedisiplinan dan kualitas interaksi yang dilakukan guru, baik kepada rekan kerja maupun siswasiswi. Pemberian umpan balik ini diharapakan mampu memotivasi guru-guru yang lain agar selalu memperbaiki semangat kerja dan termotivasi untuk meningkatkan kualitas kerja.

4. Keterampilan Peserta Didik

Selain menciptakan iklim kerja terhadap guru, sebagai output pendidikan, keberhasilan siswa juga merupakan indokator pendukung dalam menentukan apakah iklim kerja sebuah sekolah kondusif atau tidak, maka dari itu siswa memiliki posisi penting dalam hal mewujudkan sekolah yang produktif. Dalam hal ini kepala sekolah mendorong guru untuk selalu melihat dan menumbuhkembangkan potensi peserta didik melalui kegiatan ekstrakurikuler, selain faktor akademis, keterampilan menjadi pusat perhatian kepala sekolah dalam hal menciptakan peserta didik yang berkualitas dan berdaya saing. Untuk itu dalam hal meningkatkan keterampilan, kepala sekolah membuat ektrakurikuler dalam hal meningkatkan keterampilan khusunya di bidang agama, seni dan pramuka. Tidak hanya di sekolah, peningkatan keterampilan ini juga berlanjut sampai di eksternal sekolah dengan memberikan kesempatan kepada peserta didik untuk mengikuti berbagai perlombaan. Aktivitas peserta didik dalam memunculkan dan meningkatkan keterampilan menjadi salah satu factor pendukung iklim yang kondusif.

Faaktor pendukung dalam menciptakan iklim kerja diantaranya adalah adanya dukungan dari yayasan dalam melengkapi fasilitas dan sarana yang menunjang kenyamanan dalam bekrja. Dan kesadaran guru akan pentingnya team work dalam mewujudkan tujuan bersama. Sedangkan factor penghambat upaya kepala sekolah adalah perbedaan karakteristik yang dalam diri setip guru, secara personal guru memiliki emosional yang berbeda-beda. Sehingga kerap kali perbedaan itu menjadi pemicu uapaya kepala yang dilakukan kepala sekolah tidak berjalan dengan baik. 
Journal Continuous Education

Volume 1, Issue 1, November 2020

Page 43-55

\section{KESIMPULAN}

Kesimpulan penelitian ini adalah 1.Upaya Kepala Sekolah dalam menciptakan iklim kerja yang kondusif diantaranya a. Kepala sekolah menjalin komunikasi interaktif dengan guru dengan pendekatan formal maupun informal sebagai upaya menciptakan harmonisasi, b. Kepala sekolah memberikan reward apresiasi baik berupa pujian maupun hadiah sebagai bentuk apresiasi terhadap kualitas kerja guru, c. Memberikan kesempatan kepada guru untuk membantu peserta didik dalam menumbuhkembangkan keterampilan melalui kegiatan ektrakurikuler khususnya di bidang agama dan seni. 2. Faktor pendukung dan penghambat dalam upaya menciptakan iklim kerja yang kondusif. a. Kesadaran guru akan pentingnya teamwork dalam memudahkan pekerjaan, b. dukungan dari pihak yayasan dalam memfasilitasi dan menyediakan sarana yang turut mewujudkan lingkungan kerja yang nyaman bagi guru. factor penghambatnya adalah kepribadian dan prinsip personal guru yang berbeda-beda.

\section{DAFTAR PUSTAKA}

Daryanto. 2008.Administrasi Pendidika.Jakarta: Rineka Cipta

Fauziah, Agustini. 2010. Manajemen Sumberdaya Manusia Lanjutan. Medan: Madenatera

Helmawati. 2014. Meningkatkan Kinerja Kepala Sekolah/ Madrasah Melalui Manajerial Skill. Jakarta: Rieneka Cipta

Lexy J. Moleong,2009.Metodologi Penelitian Kualitatif. Bandung:Remaja Rosdakarya

Mulyasa. 2003.Manajemen Berbasis Sekolah, Bandung: Rosdakarya

Salim dan Syahrum. 2012. Metodologi Penelitian Kualitatif. Bandung; Citapustaka Media

Supardi. 2014. Kinerja Guru. Jakarta: PT. Raja Grafindo Persada

Syafaruddin dkk. 2014. Inovasi Pendidikan (Suatu Analisis Terhadap Kebijakan Baru Pendidikan). cetakan ke III (Medan:Perdana Publishing)

Wahyudi. 2012. Kepemimpinan Kepala Sekolah: Dalam Organisasi Pembelajaran. Bandung: Alfabeta

Wirawan, 2009.Evaluasi Sumber Daya Manusia: Salemba Empat. Jakarta

Zaini, M. F. (2017). Hubungan Antara Kompetensi Profesionalisme Dengan Kinerja Guru Di MAN 3 Medan. Tadbir, 1, 19-26.

Zaini, M. F. (2019). The Implementation Of Learning Management In Class Viii Madrasa Tsanawiyah Islamiyah (Mts) Ypi Batangkuis. International Conference on Islamic Educational Management (ICIEM). 